\title{
Nucleoid-associated protein HU controls three regulons that coordinate virulence, response to stress and general physiology in Salmonella enterica serovar Typhimurium
}

Correspondence

Charles J. Dorman cjdorman@tcd.ie

Received 22 October 2010

Revised 17 December 2010

Accepted 3 January 2011

\author{
Michael W. Mangan, ${ }^{1}$ Sacha Lucchini, ${ }^{2}$ Tadhg Ó Cróinín, ${ }^{1} \dagger$ \\ Stephen Fitzgerald, ${ }^{1}$ Jay C. D. Hinton ${ }^{1,2}$ and Charles J. Dorman ${ }^{1}$ \\ ${ }^{1}$ Department of Microbiology, School of Genetics and Microbiology, Moyne Institute of Preventive \\ Medicine, Trinity College, Dublin 2, Ireland \\ ${ }^{2}$ Department of Molecular Microbiology, Institute for Food Research, Colney, Norwich NR4 7UA, UK
}

The role of the HU nucleoid-associated proteins in gene regulation was examined in Salmonella enterica serovar Typhimurium. The dimeric HU protein consists of different combinations of its $\alpha$ and $\beta$ subunits. Transcriptomic analysis was performed with cultures growing at $37{ }^{\circ} \mathrm{C}$ at 1,4 and $6 \mathrm{~h}$ after inoculation with mutants that lack combinations of $\mathrm{HU} \alpha$ and $\mathrm{HU} \beta$. Distinct but overlapping patterns of gene expression were detected at each time point for each of the three mutants, revealing not one but three regulons of genes controlled by the HU proteins. Mutations in the hup genes altered the expression of regulatory and structural genes in both the SPI1 and SPI2 pathogenicity islands. The hup $A$ hupB double mutant was defective in invasion of epithelial cell lines and in its ability to survive in macrophages. The double mutant also had defective swarming activity and a competitive fitness disadvantage compared with the wild-type. In contrast, inactivation of just the hup $B$ gene resulted in increased fitness and correlated with the upregulation of members of the RpoS regulon in exponential-phase cultures. Our data show that $\mathrm{HU}$ coordinates the expression of genes involved in central metabolism and virulence and contributes to the success of $S$. enterica as a pathogen.

\section{INTRODUCTION}

The HU DNA-binding protein is one of approximately 12 nucleoid-associated proteins (NAPs) that have been described in Gram-negative bacteria such as Escherichia coli and Salmonella enterica. NAPs have the potential to influence the expression of large numbers of genes in bacteria and help to organize the nucleoid (Azam \& Ishihama, 1999; Dillon \& Dorman, 2010; Dorman \& Deighan, 2003). In Salmonella, NAPs have been shown to influence virulence gene expression (Harrison et al., 1994; O’Byrne \& Dorman, 1994a, b; Lucchini et al., 2006; Marshall

tPresent address: School of Biomolecular and Biomedical Science, Room C140, Health Science Centre, University College Dublin, Belfield, Dublin 4, Ireland.

Abbreviations: IHF, integration host factor; NAP, nucleoid-associated protein; SPI, salmonella pathogenicity island; TTSS, type three secretion system.

The microarray data reported in this paper data have been submitted to the gene expression omnibus (GEO) database with the accession number GSE22860.

Six supplementary figures and seven supplementary tables are available with the online version of this paper. et al., 1999; Navarre et al., 2006; Schechter et al., 2003). HU binds to DNA relatively non-specifically and influences many DNA-based transactions, including replication, transcription, site-specific-, general and illegitimate recombination, transposition and DNA repair (Kamashev et al., 2008; Li \& Waters, 1998; Merickel \& Johnson, 2004; Ryan et al., 2002; Semsey et al., 2004; Shanado et al., 1998; Signon \& Kleckner, 1995). It also has RNA-binding activity (Balandina et al., 2001) and a preference for binding to unusual conformations in DNA such as four-way junctions and extruded cruciform structures (Kamashev et al., 1999; Pontiggia et al., 1993; Swinger \& Rice, 2004).

$\mathrm{HU}$ is a dimer composed of two closely related subunits, HU $\alpha$ and HU $\beta$ (Guo \& Adhya, 2007) and can exist in three forms, the $\mathrm{HU} \alpha \beta$ heterodimer and the $\mathrm{HU} \alpha_{2}$ and $\mathrm{HU} \beta_{2}$ homodimers. The relative abundances of the three forms vary with the phase of growth (Claret \& Rouvière-Yaniv, 1997). The $\alpha \beta$ heterodimer is the dominant form of the protein at most stages of growth, except at the earliest stage of the exponential phase when the $\alpha_{2}$ form predominates; the $\beta_{2}$ homodimer is detectable principally in late stationary phase. The presence of three forms of HU raises the question of whether each form has unique biological properties. A key 
difference concerns the abilities of the proteins to introduce negative supercoils into DNA in the presence of topoisomerase I: the $\alpha \beta$ and $\alpha_{2}$ forms can do this, the $\beta_{2}$ form cannot (Claret \& Rouvière-Yaniv, 1997). Double mutants of E. coli that have knockout mutations in both of the genes coding for the $\alpha(h u p A)$ and $\beta$ (hupB) subunits have growth defects but remain viable (Huisman et al., 1989).

The role of $\mathrm{HU}$ in global gene regulation has not been determined previously by transcriptomic analysis in a bacterial pathogen. In the commensal organism E. coli $\mathrm{K}-12$, $\mathrm{HU}$ influences, inter alia, the expression of genes involved in anaerobic respiration, the response to osmotic stress, the acid stress response and the response to DNA damage (Kar et al., 2005; Oberto et al., 2009). S. enterica serovar Typhimurium ( $S$. Typhimurium) is an attractive subject for studies of global gene regulatory mechanisms in a pathogen because it has been characterized in great detail at the genetic and physiological levels. S. Typhimurium infects mice, where it causes a typhoid-like disease that is a valuable model for human typhoid. It can also infect other animals, such as pigs, cattle and chickens. The bacterium infects the host orally and must traverse the alimentary tract en route to the site of host cell invasion in the small intestine. This journey exposes the bacterium to a number of severe environmental stresses (e.g. the strongly acidic environment of the stomach) and $S$. Typhimurium must adjust its gene expression profile in response to each stress if it is to survive. More than 200 genes contribute to the virulence of this pathogen, with some of the best characterized being located in the chromosome within the major pathogenicity islands (Finlay \& Brumell, 2000; Groisman \& Mouslim, 2000; Groisman \& Ochman, 1997). The Salmonella pathogenicity island (SPI)1 harbours the genes that encode the Inv/Spa type III secretion system (TTSS) and its effector proteins (Galán, 2001; Hardt et al., 1998; Hensel, 2000; Mills et al., 1995; Wood et al., 1996). This TTSS is required for epithelial cell invasion while an alternative TTSS encoded by SPI2 is required for survival of $S$. Typhimurium in macrophages (Cirillo et al., 1998; Hensel, 2000; Holden, 2002; Waterman \& Holden, 2003). A third TTSS is responsible for the expression of a flagellum-dependent motile phenotype (Macnab, 2003). Previous studies have shown that NAPs act as global regulators that contribute to the coordinated expression of all three TTSSs (Dillon et al., 2010; Kelly et al., 2004; Mangan et al., 2006). The expression of many housekeeping genes is also coordinated by the gene regulatory mechanisms that operate as $S$. Typhimurium navigates the host (Eriksson et al., 2003; Hautefort et al., 2008; Hensel et al., 1995; Mahan et al., 1993; Rhen \& Dorman, 2005; Valdivia \& Falkow, 1997). Understanding how these regulatory circuits are composed and operate represents a significant challenge. We have previously determined the membership of the regulons of genes whose expression is influenced by the NAPs Fis, H-NS, IHF, Sfh and StpA in S. Typhimurium (Dillon et al., 2010; Dorman, 2007; Kelly et al., 2004; Lucchini et al., 2006, 2009; Mangan et al.,
2006). In this study we used DNA-microarray-based transcriptomics analysis to identify those genes in $S$. Typhimurium whose expression changed in the presence of mutations in hupA or hupB or both hupA and hupB.

\section{METHODS}

Bacterial strains and culture conditions. E. coli K-12 strain DH5 $\alpha$ was used as the host for cloning experiments, and strain C600 was used to assess the effect of hup gene knockouts on RpoS sigma factor expression (Oberto et al., 2009). S. Typhimurium strain SL1344, used in previous transcriptomic studies (Eriksson et al., 2003; Kelly et al., 2004; Mangan et al., 2006), was the host background for the construction of the mutant strains for transcriptome profiling. These and other strains used in this study are listed in Table 1. Bacteria were cultured in LB medium, pH 7.0 (Sambrook \& Russell, 2001) at $37{ }^{\circ} \mathrm{C}$ unless indicated otherwise. Where required, antibiotics were used at the following concentrations: carbenicillin $\left(100 \mu \mathrm{g} \mathrm{ml} \mathrm{m}^{-1}\right)$, chloramphenicol $\left(20 \mu \mathrm{g} \mathrm{ml}^{-1}\right)$, kanamycin $\left(50 \mu \mathrm{g} \mathrm{ml}^{-1}\right)$ and nalidixic acid $\left(50 \mu \mathrm{g} \mathrm{ml}^{-1}\right)$. Bacterial motility assays were performed using swarm plates containing (w/v) $1 \%$ Bacto-Tryptone, $0.5 \% \mathrm{NaCl}$ and $0.3 \%$ Bacto-Agar (Macnab, 1986). The centre of each plate was inoculated with equal numbers of bacteria and incubated at $37{ }^{\circ} \mathrm{C}$ for $8 \mathrm{~h}$. The diameter of the disc-shaped growth zone was then measured. Microbial growth in LB medium was modelled using Baranyi-Roberts approximation parameters as described previously (Perni et al., 2005).

Strain construction and DNA manipulations. Routine recombinant DNA manipulations were carried out as described by Sambrook \& Russell (2001). The plasmids used in this study are described in Table 1. Strains harbouring knockout mutations in the various genes were constructed as follows. Total genomic DNA was isolated from $S$. Typhimurium strain SL1344 using the bacterial genomic DNA purification kit (EdgeBiosystems) according to the manufacturer's instructions. Details of the oligonucleotides used in this study are presented in Supplementary Table S1 (available with the online version of this paper).

The $h u p A$ and $h u p B$ genes were knocked out by allelic exchange using the method of Datsenko \& Wanner (2000). Linear DNA for the exchange was generated by PCR using $50 \mathrm{ng}$ plasmid DNA as template, in the presence of $2.5 \mu \mathrm{M} \mathrm{dNTP}, 2.5 \mathrm{mM} \mathrm{MgCl}_{2}$, and $50 \mu \mathrm{M}$ of the appropriate oligonucleotide primer. The PCR was carried out using the Phusion polymerase and conditions recommended by the manufacturer (Finnzymes). The hupA gene was replaced on the chromosome with a kanamycin resistance cassette amplified using hupA.k.o.kan oligonucleotide primers and plasmid pSU311 as template (Uzzau et al., 2001). The hupB gene was replaced with a chloramphenicol resistance cassette generated using the combination of hup.k.o.cat primers and plasmid pKD3 as the template (Datsenko \& Wanner, 2000). S. Typhimurium CH607 was transformed with plasmid pKD46 and carbenicillin-resistant transformants were grown in LB broth supplemented with carbenicillin overnight at $30{ }^{\circ} \mathrm{C}$ with agitation. Fresh LB broth containing carbenicillin was inoculated 1:50 from this culture and incubated at $30{ }^{\circ} \mathrm{C}$ with agitation for $90 \mathrm{~min}$, before the addition of $0.02 \%(\mathrm{w} / \mathrm{v})$ arabinose to induce expression of the $\lambda$ Red recombination genes. Cells were grown to $\mathrm{OD}_{600} 0.4$, and then rapidly chilled on ice water for 10 min followed by two washes with $10 \mathrm{ml}$ sterile ice-cold water. The cell pellet was then resuspended in $1 \mathrm{ml}$ sterile ice-cold water. Aliquots $(100 \mu \mathrm{l})$ of competent $S$. Typhimurium CH607(pKD46) were transformed by electroporation with one of the purified PCR products for hup gene replacement; the cells were plated to select the desired allelic replacement at $37{ }^{\circ} \mathrm{C}$. Genomic DNA was purified from candidate mutants using the bacterial genomic DNA purification kit (EdgeBiosystems), and 
Table 1. Bacterial strains and plasmids used in this study

\begin{tabular}{|c|c|c|}
\hline Strain/plasmid & Relevant details & Reference/source \\
\hline \multicolumn{3}{|l|}{ E. coli $\mathrm{K}-12$} \\
\hline DH5 $\alpha$ & $\begin{array}{l}\text { endA1 hsdR17 }\left(\mathrm{r}_{\mathrm{K}}^{-} \mathrm{m}_{\mathrm{K}}^{+}\right) \text {glnV44 thi-1 recA1 } \\
\text { gyrA }\left(\mathrm{Nal}^{\mathrm{r}}\right) \operatorname{relA1} \Delta(\text { lacIZYA-argF) U169 deoR } \\
(\varphi 80 \Delta \text { lacZM15) }\end{array}$ & Promega \\
\hline C600 (JO2057) & thr-1 leu86 thi-1 lacY glnV44 & Oberto et al. (2009) \\
\hline JO3020 & C600 hupA:: cat hupB::kan & Oberto et al. (2009) \\
\hline \multicolumn{3}{|l|}{ S. Typhimurium } \\
\hline CH607 & LT2 polA-2 zig204: : Tn10 & Lab stocks \\
\hline CJD2000 & CH607 hupA:: cat & This study \\
\hline CJD2001 & CH607 hupB: : kan & This study \\
\hline CJD2003 & SL1344 hupA:: cat & This study \\
\hline CJD2004 & SL1344 hupB::kan & This study \\
\hline CJD2005 & SL1344 hupA:: cat hupB:: kan & This study \\
\hline SL1344 & hisG & Hoiseth \& Stocker (1981) \\
\hline SL1344 $\mathrm{Nal}^{\mathrm{r}}$ & hisG nal & Doyle et al. (2007) \\
\hline TH6232 & LT2 $\Delta$ hin7517:: FRT fliBA-OFF fliC-ON & $\begin{array}{l}\text { K.T. Hughes, University of } \\
\text { Fribourg, Switzerland }\end{array}$ \\
\hline TH6233 & LT2 $\Delta$ hin7517: : FRT fliBA-ON fliC-OFF & K.T. Hughes \\
\hline \multicolumn{3}{|l|}{ Plasmids } \\
\hline pKD3 & Template for kan cassette & Datsenko \& Wanner (2000) \\
\hline pKD46 & Inducible $\lambda$ red $B C D$ under $\mathrm{P}_{\mathrm{BAD}}$ control & Datsenko \& Wanner (2000) \\
\hline pSU311 & Template for cat cassette & Uzzau et al. (2001) \\
\hline pUC19 & oripMB1, $\mathrm{Ap}^{\mathrm{r}}$ & Yanisch-Perron et al. (1985) \\
\hline
\end{tabular}

digested with EcoRI. The hup gene alleleic replacements were confirmed by using Southern blot analysis (Sambrook \& Russell, 2001). Bacteriophage P22 transducing lysates of strains CH607hupA and CH607hupB were prepared (Sternberg \& Maurer, 1991), and used to transfer the mutated hup genes individually to $S$. Typhimurium strain SL1344. Double hupA hupB mutants were prepared by transducing either of the single hup knockouts with lysate prepared from strains lacking the alternative subunit. Serial passage of transducants on green agar plates was used to ascertain that SL1344 strains were free of P22 (Sternberg \& Maurer, 1991).

RNA isolation, microarray procedures and data analysis. To prepare cells for RNA extraction, an overnight culture grown under antibiotic selection was used to inoculate $25 \mathrm{ml}$ of fresh antibioticfree LB in a $250 \mathrm{ml}$ flask at $1: 100$, which was then incubated with shaking at 250 r.p.m. in a New Brunswick Innova 3100 waterbath at $37{ }^{\circ} \mathrm{C}$. Two biological replicates were performed for each strain and samples were removed for RNA extraction at 1,4 and $6 \mathrm{~h}$ after inoculation (Fig. 1). Twenty per cent (v/v) ice-cold RNA stabilization solution [5\% (v/v) phenol: $95 \%$ ethanol] was added with mixing and the cultures were immediately incubated on ice for $30 \mathrm{~min}$ (Kelly et al., 2004; Hinton et al., 2004). The cultures were pelleted by centrifugation $\left(3100 \mathrm{~g}, 30 \mathrm{~min}, 4{ }^{\circ} \mathrm{C}\right)$ and pellets were stored at $-80{ }^{\circ} \mathrm{C}$ until required.

RNA was extracted using a Promega SV total RNA purification kit as described previously (Kelly et al., 2004). RNA concentrations were determined from $A_{260}$, and RNA quality was assessed by using the Bioanalyser 2100 (Agilent Technologies) as directed by the manufacturer. Total RNA was diluted to $0.4 \mu \mathrm{g} \mu \mathrm{l}^{-1}$, and $4 \mu \mathrm{g}$ total RNA was used to make labelled cDNA as described by Eriksson et al. (2003). Hybridization, microarray scanning and data analysis were carried out as described previously (Kelly et al., 2004). The microarray data are provided in Supplementary Tables S2-S7, available with the online version of this paper, and are in MIAME-compliant format. The data have been submitted to the GEO database (accession number GSE22860).
Corroboration of microarray data. RT-PCR analyses were performed on transcripts using gene-specific primer pairs (Supplementary Table S1). Primers were designed in silico (http://fokker.wi.mit.edu/ primer3/) to minimize primer-primer complementarity and to yield predicted amplicons in the 150-250 bp range. Total RNA was isolated using the SV40 total RNA isolation kit (Promega), and reverse transcribed in $50 \mu \mathrm{l}$ Stratascript first-strand buffer in the presence of $0.4 \mathrm{mM}$ dNTPs, $300 \mathrm{ng}$ random hexamers and $40 \mathrm{U}$ Stratascript

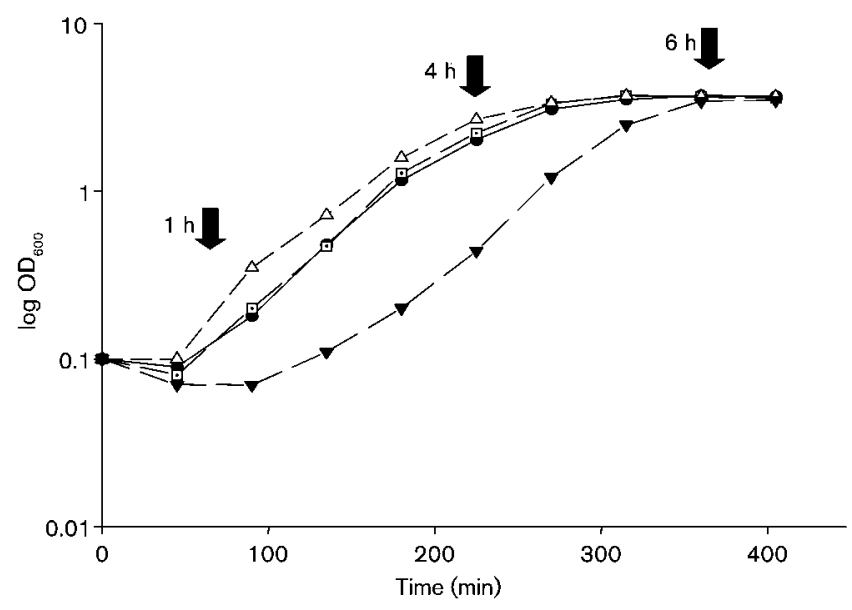

Fig. 1. Growth curves of parental strain SL1344 (O) and its three hup derivatives: hup $A(\square)$, hupB $(\triangle)$ and the double mutant $(\boldsymbol{\nabla})$ growing in LB with aeration at $37{ }^{\circ} \mathrm{C}$. The vertical arrows indicate the three time points $(1,4$ and $6 \mathrm{~h}$ ) at which RNA was extracted for the transcriptomic analyses. 
(Stratagene) according to the manufacturer's protocol. Reactions were subjected to one cycle of $94{ }^{\circ} \mathrm{C}$ for $3 \mathrm{~min}$, followed by 20-40 cycles of $94{ }^{\circ} \mathrm{C}$ for $1 \mathrm{~min}, 55{ }^{\circ} \mathrm{C}$ for $1 \mathrm{~min}$ and $72{ }^{\circ} \mathrm{C}$ for $1 \mathrm{~min}$, followed by a final extension at $72{ }^{\circ} \mathrm{C}$ for $10 \mathrm{~min}$.

Sampling of PCRs throughout the RT-PCR cycle was performed according to Grifantini et al. (2003), and products were resolved by electrophoresis on a $2 \%$ TAE agarose gel, allowing PCR regimes for the transcripts of interest to be optimized at given time points. PCR product intensities on the resulting gels were measured by using the image capture facility, and densitometry was performed using ImageJ (NIH) software. The expression of a gene at any time point in a given mutant background was recorded as a multiple of the value for the cognate wildtype sample obtained using the same cycling parameters. The STM3400 $y r d B$ gene did not respond to the absence of the HU proteins and was used as a negative control in the RT-PCR experiments (data not shown).

Measurement of competitive fitness. The competitive fitness of each of the strains was established by competitive growth assays using S. Typhimurium SL1344, SL1344hupA::kan, SL1344hupB::cat, SL1344 hupA::kan hupB::cat as test strains and the comparator strain SL1344 $\mathrm{Nal}^{\mathrm{r}}$, a spontaneously nalidixic-acid-resistant mutant, the mutation for which does not significantly affect the competitive fitness of the strain (Doyle et al., 2007). Briefly, each strain was grown overnight in LB, pH 7.0, and overnight cultures were used to establish initial (founder) populations of $10^{5}$ c.f.u. $\mathrm{ml}^{-1}$ in fresh LB broth, prewarmed to $37{ }^{\circ} \mathrm{C}$. Cultures were gently mixed, and then samples taken and serially diluted on fresh LB agar with selection appropriate to each of the strains under study. The culture was grown at $37{ }^{\circ} \mathrm{C}$ with agitation for $18 \mathrm{~h}$, and the compositions of the final populations were determined by serial dilution of the $18 \mathrm{~h}$ samples on fresh LB agar supplemented with appropriate selective agents. Competitive fitness was established as described previously (Doyle et al., 2007). Measurements were conducted in triplicate on at least three independent occasions, and each datum point presented is the average of at least nine measurements.

Western blotting. The RpoS sigma factor was detected in equivalent amounts of total protein (Bradford, 1976) from wild-type and hup mutant strains (grown in LB for $6 \mathrm{~h}$ ) by Western blotting using an antibody from NeoClone as described previously (Mangan et al., 2006).

Macrophage infection and epithelial cell invasion. Macrophage infection assays were performed on the J774.1 macrophage cell line (American type Culture Collection) maintained in Dulbecco's modified Eagle's medium with $10 \%$ fetal bovine serum. Epithelial cell invasion assays were performed with $\mathrm{CHO}$ epithelial cell lines (American type Culture Collection) maintained in Dulbecco's modified Eagle's medium with F12 Nutrient mix supplemented with $10 \%$ fetal bovine serum. Macrophage survival assays were performed with J774.1 macrophage-like cells. Both assays were carried out essentially as described previously (Marshall et al., 2000). Overnight bacterial broth cultures were diluted $1: 100$ and incubated with shaking at $37{ }^{\circ} \mathrm{C}$ overnight. The bacteria were harvested, resuspended in pre-warmed culture medium and added to $\mathrm{CHO}$ or J774.1 cells grown in 12-well plates at a m.o.i. of $100: 1$. Plates were spun at $600 \mathrm{~g}$ for $5 \mathrm{~min}$ and then incubated at $37{ }^{\circ} \mathrm{C}$ in $5 \% \mathrm{CO}_{2}$ for $2 \mathrm{~h}$ to allow invasion (epithelial cells) or phagocytosis (macrophages) to occur. The mammalian cells were then washed and incubated with fresh medium containing $100 \mu \mathrm{g}$ gentamicin $\mathrm{ml}^{-1}$ for $1 \mathrm{~h}$ to kill extracellular bacteria. The monolayers were washed and lysed by the addition of PBS containing $0.5 \%(\mathrm{v} / \mathrm{v})$ Triton X-100 to release the intracellular bacteria. The number of bacterial c.f.u. recovered was determined following serial dilution and plating on LB. The presence of the hup mutations had no effect on the sensitivity of the bacteria to Triton X-100 (data not shown). Experiments were repeated three times and typical data were reported.
Separation of plasmid topoisomers by gel electrophoresis. To investigate changes in DNA supercoiling, S. Typhimurium SL1344, CJD2003 (SL1344hupA::kan), CJD2004 (SL1344hupB::cat) and CJD2005 (SL1344 hupA::kan hupB::cat) were transformed with multicopy plasmid pUC19 by electroporation, and selection on carbenicillin. Strains were grown with carbenicillin selection in LB overnight, and subsequently inoculated into fresh LB 1:100, maintaining selection. Samples were harvested after growth for $18 \mathrm{~h}$. Plasmid DNA was recovered by using a plasmid purification kit as directed by the manufacturer (Qiagen) and separated by electrophoresis on a $0.8 \%$ agarose gel containing $2.5 \mu$ g chloroquine $\mathrm{ml}^{-1}$. Under these conditions topoisomers that are more negatively supercoiled migrate faster in the gel than more relaxed topoisomers (Higgins et al., 1988). The chloroquine gel was washed for a minimum of $5 \mathrm{~h}$ in water to remove chloroquine before staining with ethidium bromide to visualize the topoisomer bands.

\section{RESULTS AND DISCUSSION}

\section{Identification of three $\mathrm{HU}$ regulons}

Mutants of the S. Typhimurium strain SL1344 were constructed with knockout mutations in the genes coding for the $\alpha$ subunit of $\mathrm{HU}$ ( hupA, CJD2003; $\mu_{\max } 0.047 \mathrm{~min}^{-1}$ ), the $\beta$ subunit ( $h u p B, C J D 2004 ; \mu_{\max } 0.04 \mathrm{~min}^{-1}$ ), or both subunits (CJD2005; $\mu_{\max } 0.1 \mathrm{~min}^{-1}$ ) (Table 1). The single mutants had growth profiles that were similar to that of the wild-type $\left(\mu_{\max } 0.05 \mathrm{~min}^{-1}\right)$ when grown in LB broth under aerobic conditions at $37^{\circ} \mathrm{C}$; the double mutant initially showed a reduced growth rate but on entering the exponential phase of growth it grew rapidly, eventually attaining a culture OD similar to that of the wild-type by the end of exponential growth (Fig. 1). DNA microarrays were used to analyse the $S$. Typhimurium transcriptome in the presence and absence of the hup genes at three time points $(1,4$ and $6 \mathrm{~h})$ in cultures growing in LB liquid medium at $37{ }^{\circ} \mathrm{C}$.

The numbers of genes (ranging from 50 to 482) that were upregulated or downregulated differed for each of the HU mutants at each of the time points, yielding a total of 18 data points (Table 2). The mutations in just hupA or in both $h u p A$ and $h u p B$ affected approximately similar (but not identical) numbers of genes. Far fewer genes were upregulated or downregulated in the $h u p B$ single mutant at

\section{Table 2. Numbers of genes in the HU regulons}

The table summarizes the numbers of genes whose expression increased (up) or decreased (down) compared with the SL1344 wildtype in the hupA and hupB single mutants and in the hup $A$ hupB double mutant at the 1,4 and $6 \mathrm{~h}$ time points.

\begin{tabular}{|c|c|c|c|c|c|c|}
\hline \multirow[t]{2}{*}{ Strain } & \multicolumn{2}{|c|}{$1 \mathrm{~h}$} & \multicolumn{2}{|c|}{$4 \mathrm{~h}$} & \multicolumn{2}{|c|}{$6 \mathrm{~h}$} \\
\hline & Up & Down & $\mathrm{Up}$ & Down & Up & Down \\
\hline hирA & 277 & 180 & 323 & 319 & 283 & 299 \\
\hline hupB & 50 & 75 & 482 & 275 & 54 & 50 \\
\hline huрA huрB & 248 & 134 & 263 & 241 & 208 & 206 \\
\hline
\end{tabular}


(a) $1 \mathrm{~h}$

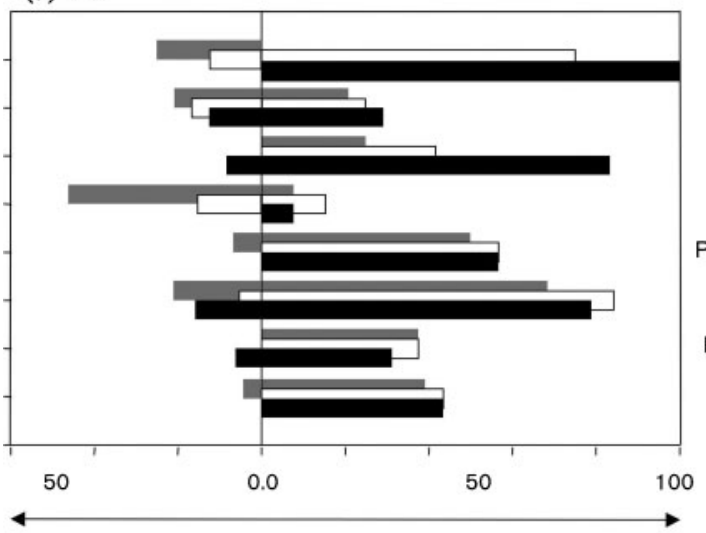

Affected genes in selected category (\%) (b) $4 \mathrm{~h}$

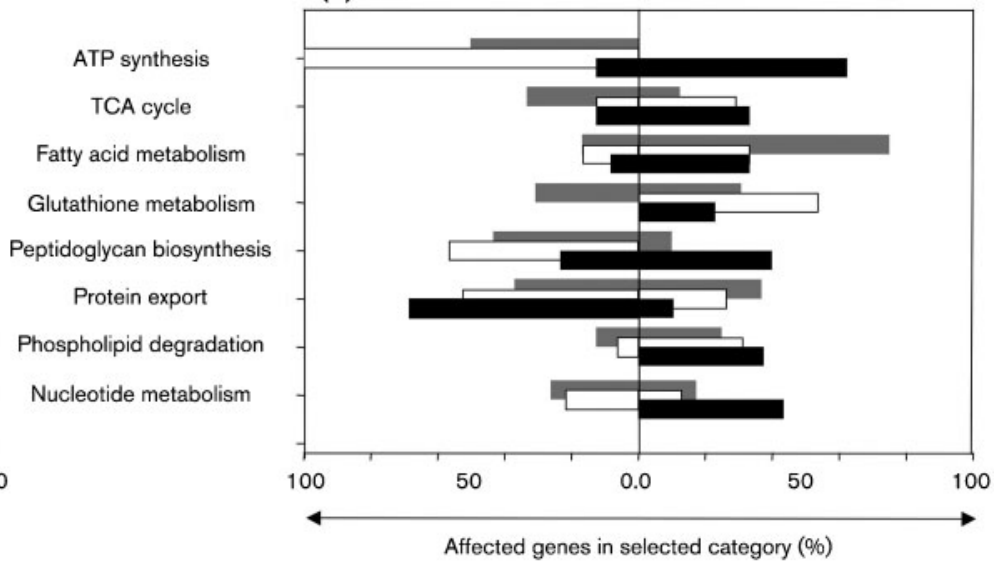

(c) $6 \mathrm{~h}$

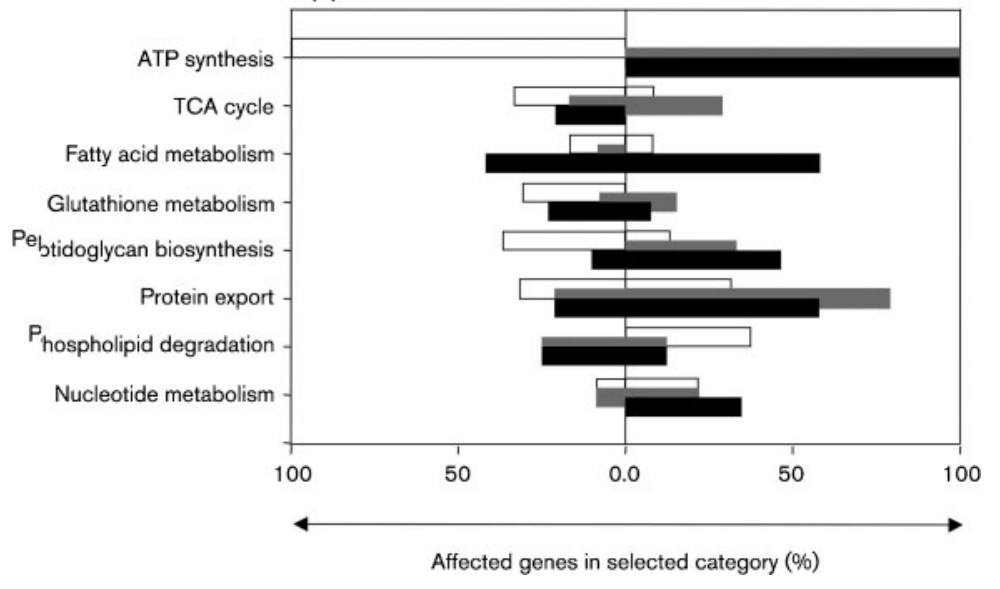

Fig. 2. Functional groups of genes influenced by HU. Data are presented for named functional groups from the Kyoto Encyclopedia of Genes and Genomics (KEGG) at 1, 4 and $6 \mathrm{~h}$ post-inoculation. The percentage of genes upregulated or downregulated at each time point is shown by the bars in the histograms. Downregulation is shown by bars to the left and upregulation by bars to the right of zero. Data are presented for the hupA mutant (grey bars), the hup $B$ mutant (white bars) and the hupA hupB double mutant (black bars).

1 and $6 \mathrm{~h}$ but this mutant had the largest number of genes upregulated at $4 \mathrm{~h}$. These differences revealed distinct regulons of genes whose expression was influenced by the three forms of $\mathrm{HU}$, and are apparent when the effects of the hup mutations on different functional groups of genes are considered; a data summary is shown in Fig. 2 where it can be seen that mutations in hupA, hupB and in both hup genes influenced a variety of metabolic processes such as ATP synthesis, the TCA cycle and fatty acid metabolism. Among horizontally acquired genetic elements, the virulence genes in the pathogenicity islands SPI1 and SPI2 were downregulated at all three time points (Figs 3 and 4). However, the effects differed between the three hup mutants and at the different time points.

\section{HU and SPI1 gene expression}

A complex regulatory cascade involving genes located within the SPI1 pathogenicity island and other regulatory genes lying elsewhere on the chromosome controls the transcription of the invasion genes in SPI1 (Rhen \& Dorman, 2005). Three SPI1 regulatory genes encode the AraC-like transcription factors HilA, HilC and HilD that upregulate the SPI1 type III secretion apparatus genes and the effector protein genes. The genes hilA, hilC and hilD were downregulated in the $h u p A$ and $h u p A$ hupB mutants at all three time points in the microarray data (Fig. 3). This was confirmed by RT-PCR and sample data are provided for hilA (Fig. 3). These transcriptomic data agreed with previous findings that knockout mutations in hupA or $h u p A$ and $h u p B$ resulted in decreased expression of these three hil regulatory genes (Schechter et al., 2003). We found that hilA, hilC and hilD were also downregulated in the $h u p B$ mutant at the 1 and $4 \mathrm{~h}$ time points, but were upregulated at $6 \mathrm{~h}$ (Fig. 3). This may account for an earlier observation that a mutation in $h u p B$ has a positive effect on the expression of hilA (Fahlen et al., 2000). The target promoters of hilA, hilC and hilD displayed a similar expression pattern. The structural genes invA, invF and invH were downregulated in each of the mutants at all of 

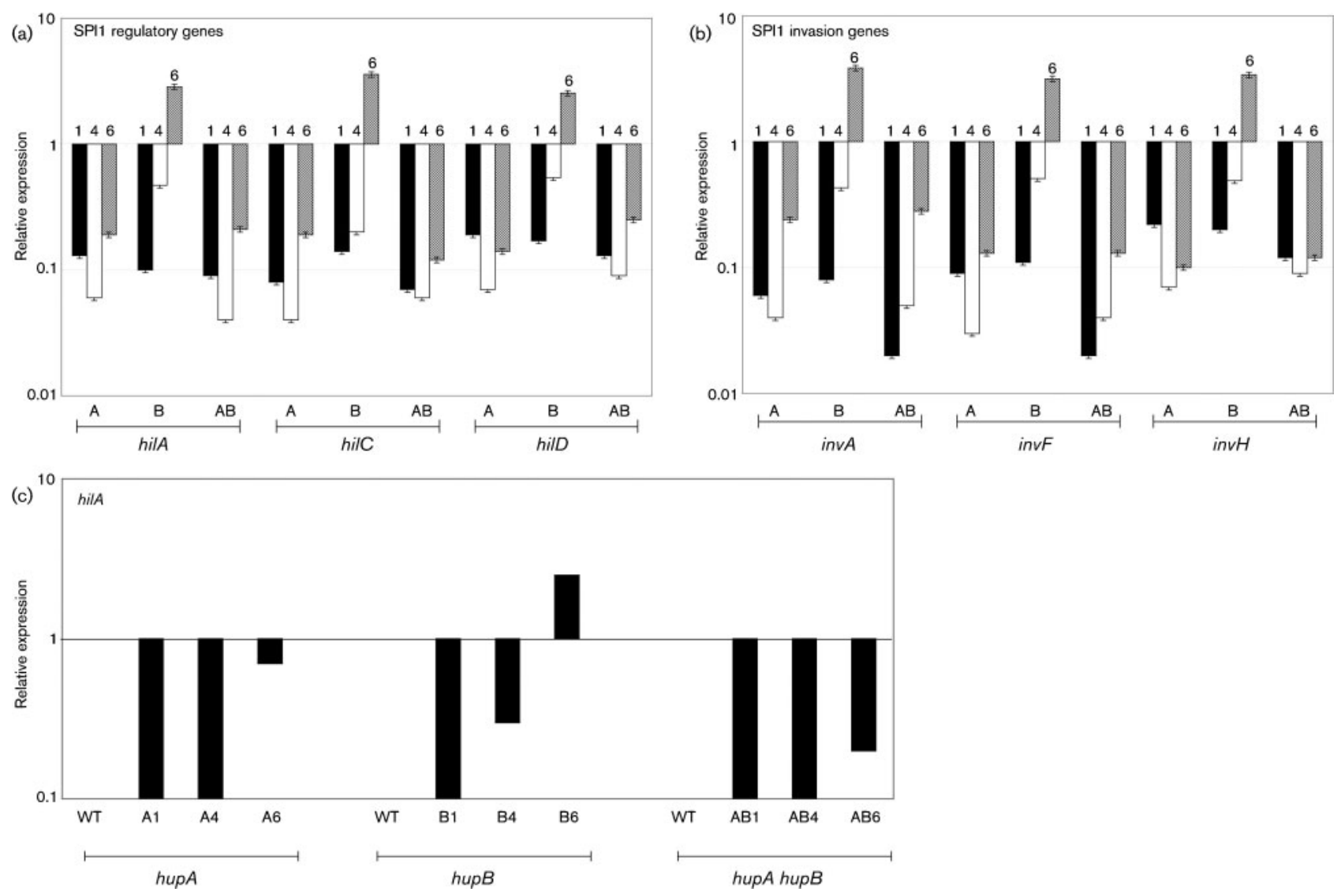

Fig. 3. Effect of the hup mutations on gene expression within the SPI1 pathogenicity island. Data are presented for SPI1 regulatory genes (a) and SPI1 invasion genes (b) in mutants deficient in hup $A(\mathrm{~A})$, hupB $(\mathrm{B})$ and hup $A$ hup $B(\mathrm{AB})$ at each of the three time points $(1,4$ and $6 \mathrm{~h}$ ). In each case, the gene expression data were normalized to SL1344 for the 1 (black), 4 (white) and 6 (grey) $\mathrm{h}$ time points and the ratio of the mutant: wild-type was calculated. Expression ratios less than 1 indicate genes normally activated by $\mathrm{HU}$ at that time point while ratios greater than 1 show where and when HU acts negatively. (c) RT-PCR data for the hilA transcript as expressed in each of the hup mutants relative to the wild-type. Error bars, SEM.

the time points, with the exception of the hupB mutant at $6 \mathrm{~h}$ where each of the three genes was upregulated (Fig. 3). Similarly, the SPI1 structural genes sipA, sipC and sipD showed a similar response to the absence of the HU proteins (Supplementary Table S3). Our results reveal an important role for each subunit of $\mathrm{HU}$ in modulating the expression of the SPI1-encoded virulence factors throughout bacterial growth. This led us to predict that mutations in the genes coding for $\mathrm{HU}$ influence the invasiveness of $S$. Typhimurium.

\section{Mutations in the hup genes alter invasiveness in epithelial cells}

The hup mutants were compared with the parental strain SL1344 for their ability to invade and proliferate in cultured epithelial cells. The invasion assays were performed as described in Methods. Bacteria were recovered from the mammalian cells after $2 \mathrm{~h}$ and the numbers of c.f.u. were determined (Table 3 ). Loss of HU $\beta$ had only a minor effect on the survival of $S$. Typhimurium growing intracellularly and was not statistically significant, in agreement with results from an earlier study (Fahlen et al., 2000). Inactivation of
hupA also resulted in a small reduction in invasion that was not statistically significant. On the other hand, the hupA hupB double mutant showed a marked reduction in epithelial cell invasion (Table 3). These data were consistent with those showing that inactivation of both the hupA and $h u p B$ genes resulted in downregulation of the SPI1 virulence genes whereas the $h u p B$ mutation had a less severe negative effect and even had a positive influence on transcription at the $6 \mathrm{~h}$ time point (Fig. 3).

\section{SPI2 gene expression, macrophage survival and the $\mathrm{HU}$ regulon}

The SPI2 pathogenicity island contains genes coding for a second TTSS and its cognate effector proteins that enable $S$. Typhimurium to survive in the hostile environment of the macrophage. SPI2 genes were also downregulated in the hupA hupB double mutant at all three time points (Fig. 4). In particular, the genes coding for the SsrA/B two-component master regulator were downregulated, as were those coding for the type III secretion apparatus (ssa). In contrast, the effector protein genes (sse) showed only minor or no 

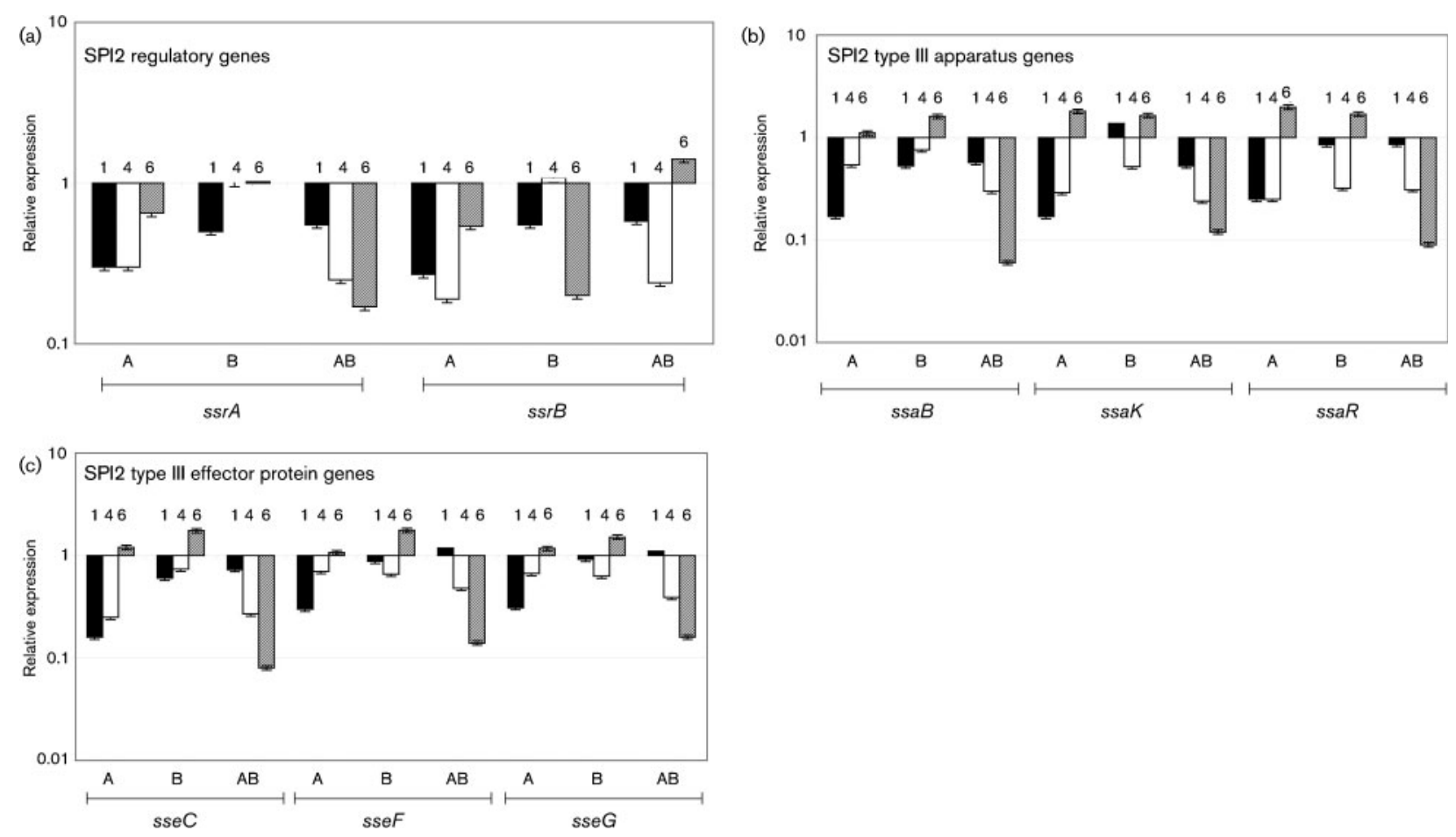

Fig. 4. Effect of the hup mutations on SPI2 gene expression. Expression data are presented for the SPI2 regulatory genes ssr $A$ and $s s r B(a)$, representative SPI2 TTSS apparatus genes (b) and representative SPI2 effector protein genes (c) in mutants deficient in hupA (A), hupB (B) and hupA hupB (AB) at each of the three time points (1, 4 and $6 \mathrm{~h}$ ). In each case, the gene expression data were normalized to SL1344 for the 1 (black), 4 (white) and 6 (grey) $h$ time points and the ratio of the mutant : wild-type was calculated. Expression ratios less than 1 indicate genes normally activated by $\mathrm{HU}$ at that time point while ratios greater than 1 show where and when $\mathrm{HU}$ acts negatively. Error bars, SEM.

reductions in expression at the $1 \mathrm{~h}$ time point, although they too were strongly downregulated at later stages of growth.

The single hupA mutant displayed reduced expression of the $s s r A$ and $s s r B$ regulatory genes, especially at the 1 and $4 \mathrm{~h}$ time points; these genes were downregulated in the $h u p B$ mutant only at the $1 \mathrm{~h}$ time point. The ssa secretion apparatus genes were downregulated in the hupA mutant at the 1 and $4 \mathrm{~h}$ time points; at $6 \mathrm{~h}$ they were upregulated in the absence of the HU $\alpha$ protein. The knockout mutation in the $h u p B$ gene had little or no effect on ssa gene expression at any time point.

The sse genes coding for the effector proteins showed reduced expression in the hupA mutant at 1 and $4 \mathrm{~h}$; at the

Table 3. Comparison of phenotypes of HU strains

Strains lacking HU subunits as indicated were compared with the SL1344 wild-type for their ability to invade epithelial cells and survive macrophage uptake after $2 \mathrm{~h}$. The patterns established at $2 \mathrm{~h}$ for the invasion and survival phenotypes were typical of those seen at 4 and $8 \mathrm{~h}$ (data not shown). The relative competitive fitness of strains lacking HU subunits was measured by co-culture for $18 \mathrm{~h}$ with SL1344 $\mathrm{Nal}^{\mathrm{r}}$, a strain harbouring a neutral selectable genetic marker (resistance to nalidixic acid; Table 1). The motility of the hup mutants was compared with the SL1344 wild-type strain on motility agar plates (see Methods). In all cases, data ( $\%$; \pm SD) are shown relative to the indicated comparator strain (100\%).

\begin{tabular}{|c|c|c|c|c|}
\hline \multirow[t]{2}{*}{ Phenotype } & \multirow[t]{2}{*}{ Comparator } & \multicolumn{3}{|c|}{ SL1344 } \\
\hline & & hupA & hupB & hирA hирв \\
\hline Epithelial cell invasion & SL1344 & $53.5 \pm 30$ & $64 \pm 33$ & $24 \pm 6^{*}$ \\
\hline Survival following macrophage uptake & SL1344 & $88.7 \pm 14$ & $111 \pm 15$ & $22 \pm 3^{*}$ \\
\hline Relative competitive fitness & SL1344 Nal ${ }^{\mathrm{r}}$ & $64 \pm 6$ & $110 \pm 4$ & $61 \pm 6$ \\
\hline Relative motility & SL1344 & $88 \pm 3^{*}$ & $50 \pm 2^{*}$ & $38 \pm 2^{*}$ \\
\hline
\end{tabular}

${ }^{\star} P$-values were calculated by paired $t$-test. Significance is denoted as $P<0.05$. 
$6 \mathrm{~h}$ time point there was no detectable effect on their transcription. Inactivation of just $h u p B$ had little effect on sse gene expression at any of the three time points.

The mutants were compared with the parental strain SL1344 for their ability to survive in J774.1 macrophages (Table 3). The presence of single mutations in the hupA or $h u p B$ genes did not have a statistically significant effect on the survival of the bacteria compared with strain SL1344. However, the hupA hupB double mutant survived much less well than the parental strain. Our results showed that $\mathrm{HU}$ contributes to the regulation of virulence genes in the two major pathogenicity islands of $S$. Typhimurium. This bacterium has a third TTSS, responsible for the secretion of flagella. We next investigated the possibility that genes involved in motility might be influenced by mutations in the hup genes.

\section{Flagella gene expression and motility are HU-dependent}

Flagellar gene expression involves a large regulon of genes that is controlled by a complex regulatory network (Brown et al., 2008; Macnab, 2003). Once the bacterial propulsion system is assembled, its activity is controlled through signals that influence the direction of flagellar motor rotation. These signals flow through a chemosensory signal transduction pathway involving reversible protein phosphorylation. Genes coding for the flagellum, its motor or the signal transduction pathway proteins showed altered expression in the hup mutants.

The effect of the hup mutations on the flagellar genes was complex and varied with the mutation and the time point (Fig. 5b). For example, genes involved in flagellar biosynthesis, such as $f l g E$, were upregulated in the absence of $h u p B$ at all three time points but downregulated in the hupA hupB double mutant at the same three time points. The hupB mutation resulted in the upregulation of most of the flagellar genes tested at least at some time points; in contrast, the mutation in hupA (and the double mutation) resulted in downregulation in almost all cases.

Motility assays on soft agar plates were used to compare the different hup mutants and the SL1344 parent strain (Table 3). The hupA mutation had the mildest effect on motility, followed by the mutation in $h u p B$ and the double hирA hupB lesions. The data did not show a clear correlation between motility as assessed by the agar plate assay and the pattern of expression of flagellar and other motility genes (Fig. 5).

\section{Respiration and metabolism}

The most dramatic effects on the expression of genes involved in respiration and metabolism occurred at the $4 \mathrm{~h}$ time point (see Supplementary Fig. S1, available with the online version of this paper). Genes involved in aerobic and in anaerobic respiration showed altered expression in the hup mutants. In particular, the cyo genes coding for cytochrome $o$ ubiquinol oxidase were strongly upregulated at the $4 \mathrm{~h}$ time point in the $h u p B$ and hupA hupB mutants. Inactivation of hupA alone did not alter their expression. This was in contrast with the situation in E. coli, where these genes are positively regulated by $\mathrm{HU}$ (Oberto et al., 2009). The narH gene, coding for nitrate reductase A, was very strongly upregulated at the $4 \mathrm{~h}$ time point, but only in the hupA mutant. The narH gene is required for anaerobic respiration in the presence of nitrate and would normally be repressed in mid-exponential-phase cultures growing under aerated conditions. HU has been reported to regulate narH positively in E. coli (Oberto et al., 2009) whereas hupA acts negatively on narH transcription in Salmonella (Supplementary Fig. S1). The nrf genes, coding for nitrite reductase, were upregulated in the hupA mutant (Supplementary Fig. S1) in agreement with data for E. coli (Oberto et al., 2009). The
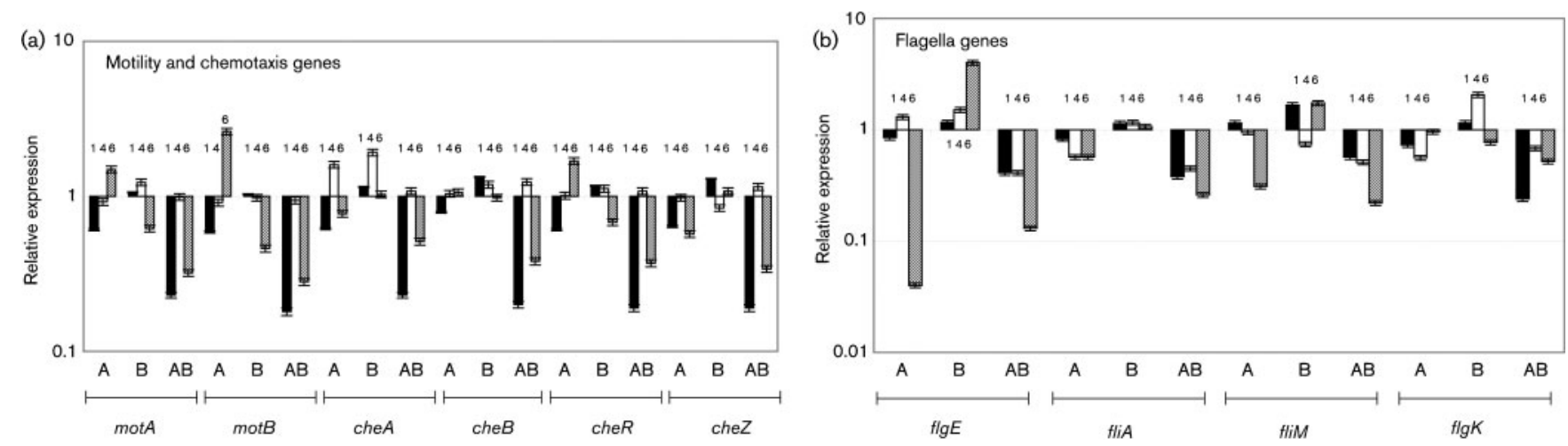

Fig. 5. Motility, chemotaxis and flagellar gene expression in the hup mutants. Data are presented for the motility and chemotaxis genes (a) and representative flagellar genes (b) in mutants deficient in hup $A(\mathrm{~A})$, hupB (B) and hup $A$ hup $B(\mathrm{AB})$ at each of the three time points (1, 4 and $6 \mathrm{~h}$ ). In each case the gene expression data were normalized to SL1344 for the 1 (black), 4 (white) and $6 \mathrm{~h}$ (grey) time points and the ratio of the mutant: wild-type was calculated. Expression ratios less than 1 indicate genes normally activated by $\mathrm{HU}$ at that time point while ratios greater than 1 show where and when $\mathrm{HU}$ acts negatively. Error bars, SEM. 
$n r f$ genes are usually expressed in bacteria growing in the absence of oxygen and in the presence of nitrite (Clarke et al., 2008). They were downregulated in the $h u p B$ and the hupA hup $B$ mutants. These data show that $\mathrm{HU} \alpha$ and $\mathrm{HU} \beta$ play distinct roles in organizing the gene expression patterns of the cell under aerobic and anaerobic growth conditions and that the detail of their contributions is not always equivalent in E. coli and Salmonella.

Propanediol utilization is an important feature of $S$. Typhimurium growth in the lumen of the mammalian gut (Bobik et al., 1999; Cheng \& Bobik, 2010; Lawhon et al., 2003). The horizontally acquired $p d u$ genes showed a strong response to hup mutations at the $4 \mathrm{~h}$ time point (see Supplementary Fig. S2, available with the online version of this paper). Here, loss of HU $\alpha$ expression resulted in upregulation of the $p d u$ operon whereas loss of both HU subunits caused these genes to be downregulated. Mutation of hupB alone had only a minor influence on $p d u$ transcription.

$\mathrm{ABC}$ transporters play key roles in nutrient uptake and scavenging (Davidson et al., 2008). The expression of genes coding for different transporters responded strongly to the loss of HU protein expression. However, the details of the response varied from system to system: e.g. expression of the dipeptide permease operon $d p p$ was most affected in the $h u p B$ mutant, while the oligopeptide permease operon $o p p$ was affected most strongly in the hupA strain and liv gene expression was affected most in the hupA hupB double mutant (see Supplementary Fig. S3, available with the online version of this paper).

\section{gal operon and regulon}

The role of the HU protein in the regulation of transcription has been worked out in most detail in the case of the galactose regulon, where the GalR DNA-binding protein represses the expression of genes involved in galactose uptake and utilization and in the transport and metabolism of other carbon sources. HU acts in the gal repressosome to facilitate the action of the GalR protein in association with DNA looping and supercoiling (Lewis et al., 2010, 1999; Semsey et al., 2004). In S. Typhimurium, inactivation of hupA resulted in the upregulation of the gal regulon genes, in keeping with the role of HU as a co-repressor (see Supplementary Table S4). However, the effect was seen only at the $1 \mathrm{~h}$ time point and only the hupA mutant showed a significant effect. These data suggest that in $S$. Typhimurium, $\mathrm{HU} \beta$ acts to modulate the action of $\mathrm{HU} \alpha$ in the Gal repressosome.

\section{HU and competitive fitness}

Measuring the fitness of different bacterial strains in competition with a common competitor is a useful method of assessing the impact of mutations on the overall physiology of the organisms. The competitive fitness of the SL1344 parental strain and those of its hup mutant derivatives were compared as described in Methods. Our results showed that the hupA mutation diminished the fitness of SL1344 whereas the $h u p B$ lesion had a positive influence (Table 3 ). Combining both mutations produced a fitness value similar to that seen when the hupA lesion alone was present. The negative effect of the hupA mutation on fitness was in line with our expectations given the number of genes whose expression was altered in its presence. Also, the absence of a negative effect on fitness due to the $h u p B$ mutation alone was consistent with the large body of data in this study showing that hupA and hupB knockout mutations have distinct impacts on cellular physiology.

\section{HU and the RpoS regulon}

A previous study established a role for $\mathrm{HU}$ in the posttranscriptional control of the RpoS stress and stationary phase sigma factor in E. coli K-12 strain C600 (Balandina et al., 2001). We found that in Salmonella, RpoS protein expression was also reduced by the inactivation of both hup genes and the earlier data for E. coli C600 (Balandina et al., 2001) were confirmed here (see Supplementary Fig. S4, available with the online version of this paper).

In our transcriptomic analysis, few members of the RpoS regulon (Lacour \& Landini, 2004; Patten et al., 2004; Weber et al., 2005) were found to respond to the presence of knockout mutations in the hup genes, when present either individually or together, with the exception of the $4 \mathrm{~h}$ time point (Fig. 6; Supplementary Tables S2-S7). This time point represented the transition from exponential growth to stationary phase in the wild-type and the two single hup mutants (Fig. 1) and was equivalent to the 'transition phase' described in an earlier study of $\mathrm{HU}$ in E. coli (Oberto et al., 2009). Here, inactivation of hupA resulted in the downregulation of many RpoS-dependent genes while the hupB mutation caused the same genes to be expressed at a higher level. The effect of the double $h u p A$ hирB mutation varied from gene to gene (Fig. 6). This pattern differed from that reported previously for E. coli hup mutants, where the mutations had either a mild or a negligible effect on the expression of the RpoS regulon (Oberto et al., 2009).

\section{HU and integration host factor (IHF)}

The HU and IHF proteins are closely related at the level of amino acid sequence but have distinct interactions with DNA (Swinger \& Rice, 2004). The $\alpha$ and $\beta$ subunits of the IHF are encoded by the ihfA and $\operatorname{ihfB}$ genes which were among the most severely downregulated in the hupA hupB double mutant at all three time points (see Supplementary Fig. S5 and Supplementary Tables S2-S7). We have previously determined the regulon of IHF in $S$. Typhimurium strain SL1344 and discovered that it includes the hupA and $h u p B$ genes, both of which are upregulated in an ihfA ihfB double mutant (Mangan et al., 2006). These results revealed a reciprocal regulatory relationship between $\mathrm{HU}$ and IHF at the level of transcription in which IHF represses hup gene transcription and HU upregulates the transcription of ihfA and $i h f B$. It is not known whether the regulatory effects are 


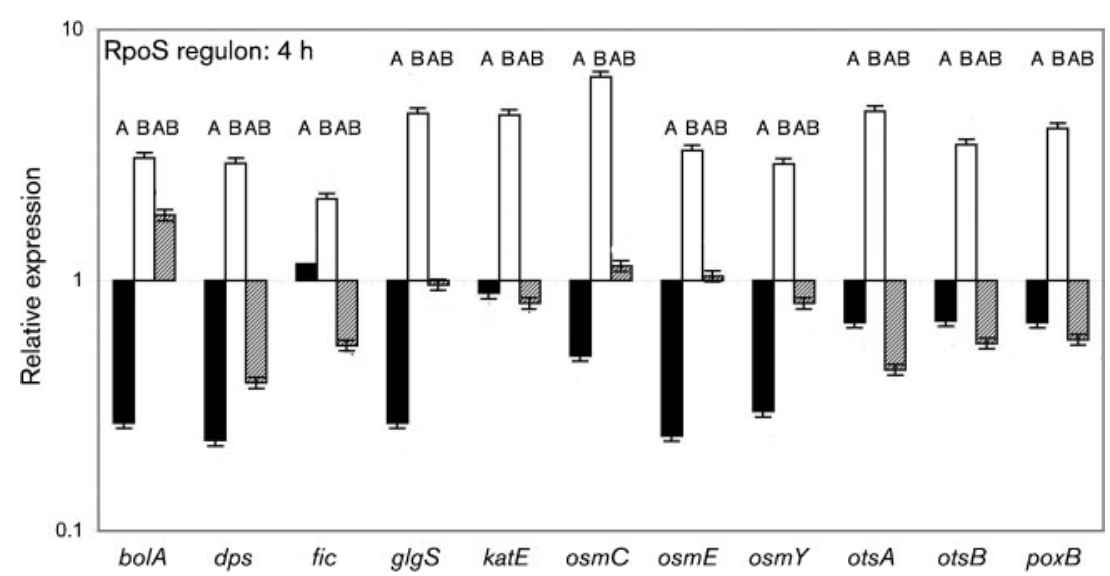

Fig. 6. Altered expression of RpoS regulon members in the hup mutants. Data are presented for representative members of the RpoS regulon in mutants deficient in hupA $(\mathrm{A})$, hup $B$ (B) and hupA hupB (AB) at the $4 \mathrm{~h}$ time point. In each case, the gene expression data were normalized to SL1344 and the ratio of the mutant:wild-type was calculated. Expression ratios less than 1 indicate genes normally activated by $\mathrm{HU}$ at that time point while ratios greater than 1 show where $\mathrm{HU}$ acts negatively. Error bars, SEM. direct, i.e. if each NAP binds at the promoters of the genes coding for the other. Our finding that HU positively regulates IHF expression may reflect some overlap between the regulons of genes under the control of these two NAPs. Certainly, the classes of genes that show altered expression in the absence of HU and IHF show a considerable overlap: the SPI1 and SPI2 virulence genes, and the chemotaxis and motility genes discussed above are HU-dependent and are also influenced by IHF (Mangan et al., 2006). However, the details of the responses vary. For example, most SPI1 virulence genes are downregulated in the absence of either HU or IHF. However, SPI1 regulatory genes are upregulated in the ihfA ihfB double mutant at the $6 \mathrm{~h}$ time point, whereas they are downregulated in the hupA hupB mutant at all time points. There is a much closer correspondence between the effects of HU and IHF among the genes of the SPI2 pathogenicity island: the $s s r A s s r B$ regulatory genes are downregulated in the absence of either HU or IHF, as are the genes coding for the secretion apparatus and the effector proteins. The motility (mot) and chemotaxis (che) genes showed similar responses to the loss of either HU or IHF at all time points but the flagellar genes showed opposite responses at $6 \mathrm{~h}$, being upregulated in the IHF-deficient strain and downregulated in the absence of HU. It is important to recall that the loss of HU results in strong downregulation of ihf gene expression, whereas the loss of IHF causes the genes coding for HU to be upregulated. For this reason knockout mutations in ihf and in hup are not equivalent.

\section{Conclusion}

This transcriptomic analysis has revealed wide-ranging roles for the HU NAP in controlling the expression of genes involved in adaptation to stress, changes in growth phase, in motility and chemotaxis and in virulence. The study shows that $S$. Typhimurium has not one but three HU regulons since inactivating the two hup genes individually and together results in distinct transcriptomic effects. In fact, in several cases (e.g. within the RpoS regulon), the loss of hupA or hupB has opposite effects on the expression of the same gene (Fig. 6). Presumably this reflects a highly dynamic relationship between HU composition and the HU-dependent genes. It is not known how many of the effects of HU on transcription reported here are direct. The complication that arises due to the influence of $\mathrm{HU}$ on the expression of IHF, another global regulator, has been discussed already. HU is also known to influence DNA supercoiling in E. coli (Claret \& Rouvière-Yaniv, 1997; Guo \& Adhya, 2007), and we found that the level of DNA supercoiling of a reporter plasmid was altered in each of the hup mutants used in this study (see Supplementary Fig S6, available with the online version of this paper). Thus, HU may exert effects at promoters through changes in DNA topology rather than through directly acting as a transcription factor or by influencing the expression of another transcription factor. Furthermore, the differences between the transcriptomes of E. coli and Salmonella mutants deficient in HU may reflect, in part, the fact that DNA in these bacteria is supercoiled to different levels (Champion \& Higgins, 2007).

Identifying the membership of the three HU regulons in $S$. Typhimurium has shown the breadth of influence of this NAP on gene expression: it is a true global regulator that coordinates the expression of central metabolism and virulence genes in $S$. Typhimurium.

\section{ACKNOWLEDGEMENTS}

We thank Gary Sawers for valuable help and insights into HU purification, Yvette Wormstone and Matthew Rolfe for printing the microarrays used in this study and Marie Doyle for advice on competitive fitness assays. Ishita Mukerji, Roger L. McMacken, and Remus Thei Dame are thanked for valuable help and insights into HU purification. We are grateful to Therese Hall for secretarial assistance and to Mike Eddington for computational support. This work was supported by a Science Foundation of Ireland Investigator Programme Grant (to C. J.D.) and a BBSRC Core Strategic Grant (to J.C. D. H.).

\section{REFERENCES}

Azam, T. A. \& Ishihama, A. (1999). Twelve species of the nucleoidassociated protein from Escherichia coli. Sequence recognition specificity and DNA binding affinity. J Biol Chem 274, 33105-33113. 
Balandina, A., Claret, L., Hengge-Aronis, R. \& Rouvière-Yaniv, J. (2001). The Escherichia coli histone-like protein HU regulates rpoS translation. Mol Microbiol 39, 1069-1079.

Bobik, T. A., Havemann, G. D., Busch, R. J., Williams, D. S. \& Aldrich, H. C. (1999). The propanediol utilization $(p d u)$ operon of Salmonella enterica serovar Typhimurium LT2 includes genes necessary for formation of polyhedral organelles involved in coenzyme $\mathrm{B}_{12^{-}}$ dependent 1, 2-propanediol degradation. J Bacteriol 181, 59675975.

Bradford, M. M. (1976). A rapid and sensitive method for the quantitation of microgram quantities of protein utilizing the principle of protein-dye binding. Anal Biochem 72, 248-254.

Brown, J. D., Saini, S., Aldridge, C., Herbert, J., Rao, C. V. \& Aldridge, P. D. (2008). The rate of protein secretion dictates the temporal dynamics of flagellar gene expression. Mol Microbiol 70, 924-937.

Champion, K. \& Higgins, N. P. (2007). Growth rate toxicity phenotypes and homeostatic supercoil control differentiate Escherichia coli from Salmonella enterica serovar Typhimurium. J Bacteriol 189, 58395849 .

Cheng, S. \& Bobik, T. A. (2010). Characterization of the PduS cobalamin reductase of Salmonella enterica and its role in the Pdu microcompartment. J Bacteriol 192, 5071-5080.

Cirillo, D. M., Valdivia, R. H., Monack, D. M. \& Falkow, S. (1998). Macrophage-dependent induction of the Salmonella pathogenicity island 2 type III secretion system and its role in intracellular survival. Mol Microbiol 30, 175-188.

Claret, L. \& Rouvière-Yaniv, J. (1997). Variation in HU composition during growth of Escherichia coli: the heterodimer is required for long term survival. J Mol Biol 273, 93-104.

Clarke, T. A., Mills, P. C., Poock, S. R., Butt, J. N., Cheesman, M. R., Cole, J. A., Hinton, J. C., Hemmings, A. M., Kemp, G. \& other authors (2008). Escherichia coli cytochrome $c$ nitrite reductase NrfA. Methods Enzymol 437, 63-77.

Datsenko, K. A. \& Wanner, B. L. (2000). One-step inactivation of chromosomal genes in Escherichia coli K-12 using PCR products. Proc Natl Acad Sci U S A 97, 6640-6645.

Davidson, A. L., Dassa, E., Orelle, C. \& Chen, J. (2008). Structure, function, and evolution of bacterial ATP-binding cassette systems. Microbiol Mol Biol Rev 72, 317-364.

Dillon, S. C. \& Dorman, C. J. (2010). Bacterial nucleoid-associated proteins, nucleoid structure and gene expression. Nat Rev Microbiol 8 , 185-195.

Dillon, S. C., Cameron, A. D. S., Hokamp, K., Lucchini, S., Hinton, J. C. D. \& Dorman, C. J. (2010). Genome-wide analysis of the H-NS and Sfh regulatory networks in Salmonella Typhimurium identifies a plasmid-encoded transcription silencing mechanism. Mol Microbiol 76, 1250-1265.

Dorman, C. J. (2007). H-NS, the genome sentinel. Nat Rev Microbiol 5, 157-161.

Dorman, C. J. \& Deighan, P. (2003). Regulation of gene expression by histone-like proteins in bacteria. Curr Opin Genet Dev 13, 179184.

Doyle, M., Fookes, M., Ivens, A., Mangan, M. W., Wain, J. \& Dorman, C. J. (2007). An H-NS-like stealth protein aids horizontal DNA transmission in bacteria. Science 315, 251-252.

Eriksson, S., Lucchini, S., Thompson, A., Rhen, M. \& Hinton, J. C. (2003). Unravelling the biology of macrophage infection by gene expression profiling of intracellular Salmonella enterica. Mol Microbiol 47, 103-118.

Fahlen, T. F., Mathur, N. \& Jones, B. D. (2000). Identification and characterization of mutants with increased expression of hilA, the invasion gene transcriptional activator of Salmonella typhimurium. FEMS Immunol Med Microbiol 28, 25-35.

Finlay, B. B. \& Brumell, J. H. (2000). Salmonella interactions with host cells: in vitro to in vivo. Philos Trans R Soc Lond B Biol Sci 355, 623631.

Galán, J. E. (2001). Salmonella interactions with host cells: type III secretion at work. Annu Rev Cell Dev Biol 17, 53-86.

Grifantini, R., Sebastian, S., Frigimelica, E., Draghi, M., Bartolini, E., Muzzi, A., Rappuoli, R., Grandi, G. \& Genco, C. A. (2003). Identification of iron-activated and -repressed Fur-dependent genes by transcriptome analysis of Neisseria meningitidis group B. Proc Natl Acad Sci U S A 100, 9542-9547.

Groisman, E. A. \& Mouslim, C. (2000). Molecular mechanisms of Salmonella pathogenesis. Curr Opin Infect Dis 13, 519-522.

Groisman, E. A. \& Ochman, H. (1997). How Salmonella became a pathogen. Trends Microbiol 5, 343-349.

Guo, F. \& Adhya, S. (2007). Spiral structure of Escherichia coli $\mathrm{HU} \alpha \beta$ provides foundation for DNA supercoiling. Proc Natl Acad Sci U S A 104, 4309-4314.

Hardt, W. D., Chen, L. M., Schuebel, K. E., Bustelo, X. R. \& Galán, J. E. (1998). S. typhimurium encodes an activator of Rho GTPases that induces membrane ruffling and nuclear responses in host cells. Cell 93, 815-826.

Harrison, J. A., Pickard, D., Higgins, C. F., Khan, A., Chatfield, S. N., Ali, T., Dorman, C. J., Hormaeche, C. E. \& Dougan, G. (1994). Role of $h n s$ in the virulence phenotype of pathogenic salmonellae. Mol Microbiol 13, 133-140.

Hautefort, I., Thompson, A., Eriksson-Ygberg, S., Parker, M. L., Lucchini, S., Danino, V., Bongaerts, R. J., Ahmad, N., Rhen, M. \& Hinton, J. C. (2008). During infection of epithelial cells Salmonella enterica serovar Typhimurium undergoes a time-dependent transcriptional adaptation that results in simultaneous expression of three type 3 secretion systems. Cell Microbiol 10, 958-984.

Hensel, M. (2000). Salmonella pathogenicity island 2. Mol Microbiol 36, 1015-1023.

Hensel, M., Shea, J. E., Gleeson, C., Jones, M. D., Dalton, E. \& Holden, D. W. (1995). Simultaneous identification of bacterial virulence genes by negative selection. Science 269, 400-403.

Higgins, C. F., Dorman, C. J., Stirling, D. A., Waddell, L., Booth, I. R., May, G. \& Bremer, E. (1988). A physiological role for DNA supercoiling in the osmotic regulation of gene expression in S. typhimurium and $E$. coli. Cell 52, 569-584.

Hinton, J. C. D., Hautefort, I., Eriksson, S., Thompson, A. \& Rhen, M. (2004). Benefits and pitfalls of using microarrays to monitor bacterial gene expression during infection. Curr Opin Microbiol 7, 277-282.

Hoiseth, S. K. \& Stocker, B. A. (1981). Aromatic-dependent Salmonella typhimurium are non-virulent and effective as live vaccines. Nature 291, 238-239.

Holden, D. W. (2002). Trafficking of the Salmonella vacuole in macrophages. Traffic 3, 161-169.

Huisman, O., Faelen, M., Girard, D., Jaffé, A., Toussaint, A. \& Rouvière-Yaniv, J. (1989). Multiple defects in Escherichia coli mutants lacking HU protein. J Bacteriol 171, 3704-3712.

Kamashev, D., Balandina, A. \& Rouvière-Yaniv, J. (1999). The binding motif recognized by $\mathrm{HU}$ on both nicked and cruciform DNA. EMBO J 18, 5434-5444.

Kamashev, D., Balandina, A., Mazur, A. K., Arimondo, P. B. \& Rouvière-Yaniv, J. (2008). HU binds and folds single-stranded DNA. Nucleic Acids Res 36, 1026-1036. 
Kar, S., Edgar, R. \& Adhya, S. (2005). Nucleoid remodeling by an altered HU protein: reorganization of the transcription program. Proc Natl Acad Sci U S A 102, 16397-16402.

Kelly, A., Goldberg, M. D., Carroll, R. K., Danino, V., Hinton, J. C. D. \& Dorman, C. J. (2004). A global role for Fis in the transcriptional control of metabolism and type III secretion in Salmonella enterica serovar Typhimurium. Microbiology 150, 2037-2053.

Lacour, S. \& Landini, P. (2004). $\sigma^{\mathrm{S}}$-dependent gene expression at the onset of stationary phase in Escherichia coli: function of $\sigma^{\mathrm{S}}$-dependent genes and identification of their promoter sequences. J Bacteriol 186, 7186-7195

Lawhon, S. D., Frye, J. G., Suyemoto, M., Porwollik, S., McClelland, M. \& Altier, C. (2003). Global regulation by CsrA in Salmonella typhimurium. Mol Microbiol 48, 1633-1645.

Lewis, D. E., Geanacopoulos, M. \& Adhya, S. (1999). Role of HU and DNA supercoiling in transcription repression: specialized nucleoprotein repression complex at gal promoters in Escherichia coli. Mol Microbiol 31, 451-461.

Lewis, D. E. A., Lee, S. J. \& Adhya, S. (2010). Role of HU in regulation of gal promoters. In Bacterial Chromatin, pp. 395-417. Edited by R. T. Dame \& C. J. Dorman. Heidelberg: Springer.

Li, S. \& Waters, R. (1998). Escherichia coli strains lacking protein HU are UV sensitive due to a role for $\mathrm{HU}$ in homologous recombination. J Bacteriol 180, 3750-3756.

Lucchini, S., Rowley, G., Goldberg, M. D., Hurd, D., Harrison, M. \& Hinton, J. C. D. (2006). H-NS mediates the silencing of laterally acquired genes in bacteria. PLoS Pathog 2, e81.

Lucchini, S., McDermott, P., Thompson, A. \& Hinton, J. C. (2009). The H-NS-like protein StpA represses the RpoS $\left(\sigma^{38}\right)$ regulon during exponential growth of Salmonella Typhimurium. Mol Microbiol 74, 1169-1186.

Macnab, R. M. (1986). Proton-driven bacterial flagellar motor. Methods Enzymol 125, 563-581.

Macnab, R. M. (2003). How bacteria assemble flagella. Annu Rev Microbiol 57, 77-100.

Mahan, M. J., Slauch, J. M. \& Mekalanos, J. J. (1993). Selection of bacterial virulence genes that are specifically induced in host tissues. Science 259, 686-688.

Mangan, M. W., Lucchini, S., Danino, V., Ó Cróinín, T., Hinton, J. C. D. \& Dorman, C. J. (2006). The integration host factor (IHF) integrates stationary-phase and virulence gene expression in Salmonella enterica serovar Typhimurium. Mol Microbiol 59, 1831-1847.

Marshall, D. G., Sheehan, B. J. \& Dorman, C. J. (1999). A role for the leucine-responsive regulatory protein and integration host factor in the regulation of the Salmonella plasmid virulence $(s p v)$ locus in Salmonella typhimurium. Mol Microbiol 34, 134-145.

Marshall, D. G., Bowe, F., Hale, C., Dougan, G. \& Dorman, C. J. (2000). DNA topology and adaptation of Salmonella typhimurium to an intracellular environment. Philos Trans R Soc Lond B Biol Sci 355, $565-574$.

Merickel, S. K. \& Johnson, R. C. (2004). Topological analysis of Hincatalysed DNA recombination in vivo and in vitro. Mol Microbiol 51, 1143-1154.

Mills, D. M., Bajaj, V. \& Lee, C. A. (1995). A $40 \mathrm{~kb}$ chromosomal fragment encoding Salmonella typhimurium invasion genes is absent from the corresponding region of the Escherichia coli K-12 chromosome. Mol Microbiol 15, 749-759.

Navarre, W. W., Porwollik, S., Wang, Y., McClelland, M., Rosen, H., Libby, S. J. \& Fang, F. C. (2006). Selective silencing of foreign DNA with low GC content by the H-NS protein in Salmonella. Science 313, 236-238.
O'Byrne, C. P. \& Dorman, C. J. (1994a). The $s p v$ virulence operon of Salmonella typhimurium LT2 is regulated negatively by the cyclic AMP (cAMP)-cAMP receptor protein system. J Bacteriol 176, 905-912.

O'Byrne, C. P. \& Dorman, C. J. (1994b). Transcription of the Salmonella typhimurium $s p v$ virulence locus is regulated negatively by the nucleoid-associated protein H-NS. FEMS Microbiol Lett 121, 99 105.

Oberto, J., Nabti, S., Jooste, V., Mignot, H. \& Rouvière-Yaniv, J. (2009). The HU regulon is composed of genes responding to anaerobiosis, acid stress, high osmolarity and SOS induction. PLoS ONE 4, e4367.

Patten, C. L., Kirchhof, M. G., Schertzberg, M. R., Morton, R. A. \& Schellhorn, H. E. (2004). Microarray analysis of RpoS-mediated gene expression in Escherichia coli K-12. Mol Genet Genomics 272, 580-591.

Perni, S., Andrew, P. W. \& Shama, G. (2005). Estimating the maximum growth rate from microbial growth curves: definition is everything. Food Microbiol 22, 491-495.

Pontiggia, A., Negri, A., Beltrame, M. \& Bianchi, M. E. (1993). Protein HU binds specifically to kinked DNA. Mol Microbiol 7, 343-350.

Rhen, M. \& Dorman, C. J. (2005). Hierarchical gene regulators adapt Salmonella enterica to its host milieus. Int J Med Microbiol 294, 487502.

Ryan, V. T., Grimwade, J. E., Nievera, C. J. \& Leonard, A. C. (2002). IHF and HU stimulate assembly of pre-replication complexes at Escherichia coli oriC by two different mechanisms. Mol Microbiol 46, 113-124.

Sambrook, J. \& Russell, D. (2001). Molecular Cloning: a Laboratory Manual. Cold Spring Harbor, NY: Cold Spring Harbor Laboratory.

Schechter, L. M., Jain, S., Akbar, S. \& Lee, C. A. (2003). The small nucleoid-binding proteins $\mathrm{H}-\mathrm{NS}$, HU, and Fis affect hilA expression in Salmonella enterica serovar Typhimurium. Infect Immun 71, 54325435.

Semsey, S., Tolstorukov, M. Y., Virnik, K., Zhurkin, V. B. \& Adhya, S. (2004). DNA trajectory in the Gal repressosome. Genes Dev 18, 18981907.

Shanado, Y., Kato, J. \& Ikeda, H. (1998). Escherichia coli HU protein suppresses DNA-gyrase-mediated illegitimate recombination and SOS induction. Genes Cells 3, 511-520.

Signon, L. \& Kleckner, N. (1995). Negative and positive regulation of Tn10/IS10-promoted recombination by IHF: two distinguishable processes inhibit transposition off of multicopy plasmid replicons and activate chromosomal events that favor evolution of new transposons. Genes Dev 9, 1123-1136.

Sternberg, N. L. \& Maurer, R. (1991). Bacteriophage-mediated generalized transduction in Escherichia coli and Salmonella typhimurium. Methods Enzymol 204, 18-43.

Swinger, K. K. \& Rice, P. A. (2004). IHF and HU: flexible architects of bent DNA. Curr Opin Struct Biol 14, 28-35.

Uzzau, S., Figueroa-Bossi, N., Rubino, S. \& Bossi, L. (2001). Epitope tagging of chromosomal genes in Salmonella. Proc Natl Acad Sci U S A 98, 15264-15269.

Valdivia, R. H. \& Falkow, S. (1997). Fluorescence-based isolation of bacterial genes expressed within host cells. Science 277, 2007-2011.

Waterman, S. R. \& Holden, D. W. (2003). Functions and effectors of the Salmonella pathogenicity island 2 type III secretion system. Cell Microbiol 5, 501-511.

Weber, H., Polen, T., Heuveling, J., Wendisch, V. F. \& Hengge, R. (2005). Genome-wide analysis of the general stress response network in Escherichia coli: $\sigma^{\mathrm{S}}$-dependent genes, promoters, and sigma factor selectivity. J Bacteriol 187, 1591-1603. 
Wood, M. W., Rosqvist, R., Mullan, P. B., Edwards, M. H. \& Galyov, E. E. (1996). SopE, a secreted protein of Salmonella dublin, is translocated into the target eukaryotic cell via a sip-dependent mechanism and promotes bacterial entry. Mol Microbiol 22, 327338.
Yanisch-Perron, C., Vieira, J. \& Messing, J. (1985). Improved M13 phage cloning vectors and host strains: nucleotide sequences of the M13mp18 and pUC19 vectors. Gene 33, 103-119.

Edited by: D. W. Ussery 